\title{
Acanthocephalan parasites: help or burden in gammarid amphipods exposed to cadmium?
}

\author{
E. Gismondi $\cdot$ C. Cossu-Leguille $\cdot$ J.-N. Beisel
}

Accepted: 11 February 2012/Published online: 30 March 2012

(C) Springer Science+Business Media, LLC 2012

\begin{abstract}
We investigated the influence of the acanthocephalan parasite Polymorphus minutus on the mortality of its intermediate host, Gammarus roeseli, exposed to cadmium, by the measure of $\mathrm{LC}_{50-96 \mathrm{~h}}$ values as well as the bioaccumulation of cadmium both in the host and in its parasite. $\mathrm{LC}_{50}$ results revealed that infected $G$. roeseli males died less under cadmium stress than uninfected ones; while the converse has been observed in females. Cadmium resistance of infected males could be explained by a weaker bioconcentration factor (BCF) than in females. The lower BCF in infected individuals was closely related with an uptake of cadmium by $P$. minutus in its host. Nevertheless, although infected females had both weaker BCF and cadmium concentration in their body, the presence of $P$. minutus did not induce lower mortality than uninfected females. On the contrary, their sensitivity to cadmium was increased by the presence of $P$. minutus. We discuss the hypothesis that differences of mortality between uninfected and infected gammarids could be explained by a difference of cadmium bioconcentration in host, and by the cadmium bioaccumulation in the parasite. Indeed, results suggested that $P$. minutus could help G. roeseli to face with stress, what contributed to keep the host alive and favour the parasite transmission.
\end{abstract}

Keywords Cadmium - Parasitism - Gammarus roeseli . Polymorphus minutus $\cdot \mathrm{LC}_{50} \cdot \mathrm{BCF}$

\footnotetext{
E. Gismondi $(\square) \cdot$ C. Cossu-Leguille $\cdot$ J.-N. Beisel Laboratoire des Interactions Ecotoxicologie Biodiversité Ecosystèmes (LIEBE) Laboratory, CNRS UMR 7146, Université de Lorraine (UdL), Campus Bridoux, Avenue du Général Delestraint, 57070 Metz, France

e-mail: eric.gismondi@hotmail.fr
}

\section{Introduction}

In recent years, there has been an increase of interest about the influence of parasite in their host under environmental contaminations. Parasites are known to disrupt behavioural and physiological host responses (Sures 2004; Marcogliese and Pietrock 2011), and several studies underlined the parasite influence on host responses when exposed to pollutants. Marcogliese et al. (2005) described an increase of antitoxic enzymes activities (i.e. catalase, glutathione $S$-transferase) in the yellow perch infected by nematode and digenean parasites in river impacted by several metals. In contrast, a depletion of the antitoxic defences has been observed in digenean-infected cockles exposed to cadmium (Baudrimont et al. 2006) or in zebra mussels infected by Ophryoglena sp. exposed to a multistress environment (Minguez et al. 2009). This decrease of antitoxic defence compounds could lead to an increase of host damage as it was the case in Gammarus roeseli infected by verticallytransmitted microsporidia parasites exposed to cadmium (Gismondi et al. 2012).

In the case of complex life cycles, parasite uses at least one intermediate host to its larval development and a final host to mature and reproduce. Among the numerous complex life cycle parasites, acanthocephalans are known to alter the phenotype of their intermediate hosts in a way that make it more prone to predation and thus, favour its transmission to the final vertebrate host (Kennedy 2006; Lagrue et al. 2007). If behavioural changes induced by the parasite have been intensively studied (Cézilly et al. 2000; Bauer et al. 2005; Médoc et al. 2006), the modifications of host antitoxic responses has become a topic of interest in a context of rising pollution in freshwater ecosystems. Sures and Radszuweit (2007) described that the cystacanth stage of Polymorphus minutus prevented the synthesis of heat 
shock protein 70 in $G$. roeseli, when subjected to a thermal disturbance or a palladium exposure. Cornet et al. (2009) have shown a decrease of the prophenoloxidase system and the haemocyte concentration, two major parameters of crustacean immunity, in Gammarus pulex infected by three acanthocephalan parasites: Pomphorhynchus laevis, $P$. tereticollis and P. minutus.

Because acanthocephalan parasites need their host to survive both for their own development and for their transmission to a definitive host (Plaistow et al. 2001), we hypothesized that parasite could help its intermediate host to cope with stress conditions, what favours its transmission to the final host. We also hypothesized that the decrease of antitoxic defences already shown in previous ecotoxicological studies could be due to the fact that the host could need less defences to face with stress.

We tested our hypothesis in the widespread amphipod $G$. roeseli, an intermediate host for the acanthocephalan parasite $P$. minutus, which modifies the gammarid behaviour (Médoc et al. 2006; Médoc and Beisel 2009). We first studied the influence of the acanthocephalan parasite $P$. minutus on the lethal concentration 50 of cadmium ( $\mathrm{LC}_{50}$ - concentration that caused the death of $50 \%$ of individuals) reflecting the resistance of the gammarid host. Then, we compared the cadmium accumulation in the body-whole of uninfected and infected $G$. roeseli after having removed parasites. The accumulation of cadmium was also measured in the body-whole of $P$. minutus extracted from its host.

\section{Materials and methods}

\section{Sampling collection and maintenance}

Gammarus roeseli uninfected and infected by $P$. minutus were collected in April 2010 with a pond net in the French Nied River (Rémilly, North-eastern France, $49^{\circ} 00^{\prime} \mathrm{N}$ and $\left.6^{\circ} 23^{\prime} \mathrm{E}\right)$, where cadmium concentrations were less than $0.2 \mu \mathrm{g} \mathrm{L}^{-1}$ (unpublished data). Infected $G$. roeseli were easily identified thanks to the cystacanth stage of $P$. minutus appearing as an intense orange dot through the cuticle. Individual gammarids were sorted in field after observation of the gnathopod size, a sexually dimorphic character, males having gnathopod size larger than females. Gammarids were transferred to the laboratory in containers filled with river water, and then acclimated at $15^{\circ} \mathrm{C}$ in an EDTA-free Elendt M4 solution. Animals were fed ad libitum with alder leaves and acclimated 5 days in these conditions before being used in experiments. This acclimation period allows selecting only healthy individuals for the experiment.
$\mathrm{LC}_{50}$ assessment

This experimentation aimed at determining the cadmium $\mathrm{LC}_{50}$ values of $G$. roeseli uninfected and infected by $P$. minutus. Four conditions were tested according to the gender and the infection status (i.e. uninfected versus $P$. minutus-infected). Five different cadmium concentrations were prepared using a $12 \mathrm{mg} \mathrm{L}^{-1}$ of $\mathrm{CdCl}_{2}$ stock solution and Elendt M4 modified solution: 0, 6, 18, 54 and $162 \mu \mathrm{g} \mathrm{Cd} \mathrm{L}{ }^{-1}$. These concentrations were chosen according to a preliminary cadmium exposition (data not shown) and the $\mathrm{LC}_{50-96 \mathrm{~h}}$ observed by Felten et al. (2008) in G. pulex $\left(82.1 \mu \mathrm{g} \mathrm{Cd} \mathrm{L}^{-1}\right)$. Three replicates of 10 gammarids were exposed at $15^{\circ} \mathrm{C}$ for $96 \mathrm{~h}$ to the 5 cadmium concentrations in $500 \mathrm{~mL}$ glass tank with a photoperiod of 14:10 (d:n) and without alimentary resource. Dead individuals were removed each $24 \mathrm{~h}$ to avoid cannibalism and survivors were counted at the end of the experimentation.

\section{Cadmium accumulation}

At the end of the exposure, alive uninfected and infected $G$. roeseli of each gender, exposed to each cadmium condition, were immediately frozen at $-196^{\circ} \mathrm{C}$ and stored at $-80^{\circ} \mathrm{C}$ awaiting the cadmium analysis, taking care to remove the cystacanth from the infected hosts. Similarly, five pools of five cystacanths were carried out being careful to separate the parasites from infected males and infected females, and stored as above prior to cadmium analysis. Due to high mortality rates in the highest cadmium concentrations, the cadmium analysis was conducted only on $G$. roeseli exposed to the first three concentrations: 0, 6 and $18 \mu \mathrm{g} \mathrm{Cd} \mathrm{L}{ }^{-1}$.

To analyze cadmium concentration, samples were dried at $100^{\circ} \mathrm{C}$ during $48 \mathrm{~h}$, and weighted. Then, they were digested with $50 \mu \mathrm{L}$ Suprapur nitric acid $\left(\mathrm{HNO}_{3}\right)$ at $80^{\circ} \mathrm{C}$ for a minimum of $12 \mathrm{~h}$ until a limpid solution was obtained. The volume was then adjusted to $1 \mathrm{~mL}$ with deionized water. Cadmium was measured in these acid solutions by flameless atomic absorption spectrophotometry (AAS). Cadmium controls were based on the Spectrapure standards AS-SPS quality control material (Oslo, Norway). The cadmium accumulation was expressed in $\mathrm{ng} \mathrm{Cd} \mathrm{mg}^{-1}$ dry weight.

The bioconcentration factors (BCF) were calculated using the method of Taylor (1983) described in Duquesne et al. (2000). BCFs were only estimated for $G$. roeseli due to the fact that $P$. minutus are located in haemolymph of the gammarid and thus, not exposed to cadmium concentration in the water. Moreover, the bioaccumulation of cadmium was measured in the body-whole of $G$. roeseli, so we could not estimate that this value also corresponded to the concentration of cadmium in the haemolymph, concentration at which the cystacanth was exposed. 
Statistical analysis

$\mathrm{LC}_{50-96 \mathrm{~h}}$ values were estimated by using the Excel macro REGTOX according to the method of Vindimian et al. (1999). Statistical comparisons of cadmium accumulation data were performed using a two way-ANOVAs following by the post hoc HSD Tukey tests, after having log transformed data to meet the normality and the variance homogeneity conditions. Similarly, significant differences of BCFs were tested using three way-ANOVAs followed by post hoc HSD Tukey tests. All tests were two-tailed with significant differences considered at the level of $p \leq 0.05$.

\section{Results}

$\mathrm{LC}_{50}$ assessment

Results of $\mathrm{LC}_{50-96 \mathrm{~h}}$ values according to gender and infection status of $G$. roeseli were summarized in Table 1. Cadmium sensitivity was different according to gender. Indeed, uninfected females were twice more resistant to cadmium than uninfected males. However, when G. roeseli were infected by $P$. minutus, males were four times more resistant to cadmium than females. Finally, results shown that $P$. minutus-infected males were twice less sensitive to cadmium than uninfected ones; while $P$. minutus-infected females were three times more sensitive than uninfected ones.

\section{Cadmium accumulation}

After $96 \mathrm{~h}$ of cadmium exposure, there was a doseresponse relationship for the cadmium accumulation in $G$. roeseli, whatever the gender and infection status (Fig. 1). Indeed, whatsoever the gender, cadmium concentrations in uninfected gammarids exposed at 6 and $18 \mu \mathrm{g} \mathrm{Cd} \mathrm{L} \mathrm{C}^{-1}$ were on average 12 and 24 times higher than controls. When $P$. minutus was present, cadmium concentrations in exposed males were 4 and 10-fold higher than their controls; while in exposed females, they were 12 and 20 -fold higher than unexposed ones. Results have also shown that cadmium accumulation in gammarids was higher in absence of $P$. minutus whatever the cadmium exposure. In

Table 1 LC $_{50-96 \mathrm{~h}}$ values ( $\pm 95 \%$ confidence interval) of Gammarus roeseli according to gender and the presence/absence of Polymorphus minutus, after $96 \mathrm{~h}$ of cadmium exposure ( $n=30$ for each condition)

$\mathrm{LC}_{50-96 \mathrm{~h}}\left(\mu \mathrm{g} \mathrm{Cd} \mathrm{L}^{-1}\right)$

\begin{tabular}{lllll}
\hline Males & & & Females \\
\cline { 1 - 1 } Uninfected & Infected & & Uninfected & Infected \\
\hline $50(26-92)$ & $146(94-269)$ & & $107(72-167)$ & $35(25-50)$ \\
\hline
\end{tabular}

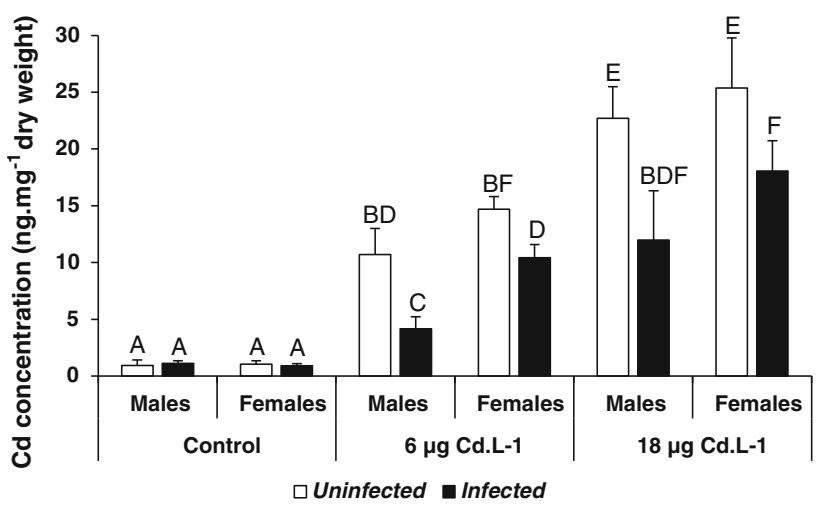

Fig. 1 Concentrations of cadmium measured in $G$. roeseli exposed at 6 and $18 \mu \mathrm{g} \mathrm{Cd} \mathrm{L}^{-1}$ according to the gender and the infected status. Five individuals were analyzed for each condition. Different letters above the bars indicate significantly different values $(p$ values $<0.05$ )

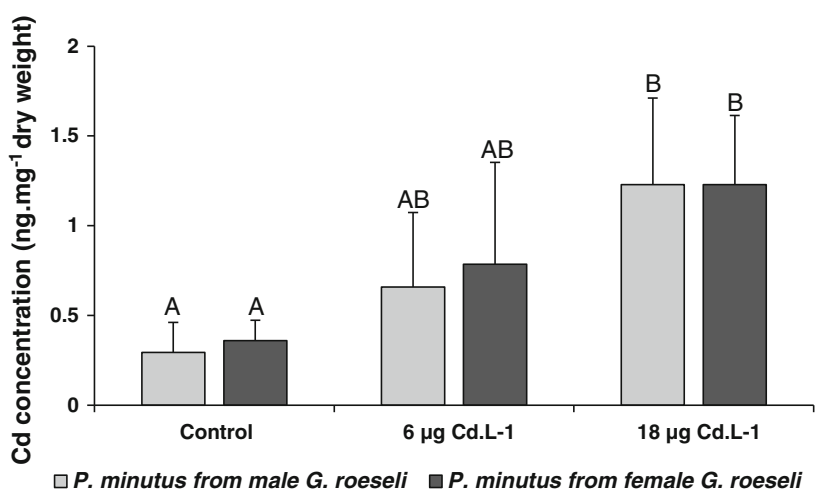

Fig. 2 Concentrations of cadmium determined in P. minutus from $G$. roeseli males and females exposed at 6 and $18 \mu \mathrm{g} \mathrm{Cd} \mathrm{L}^{-1}$. Five pools of five cystacanths were analyzed for each condition. Different letters above the bars indicate significantly different values $(p$ values $<0.05)$

fact, infected males had accumulated in average twice less cadmium than uninfected ones; while infected female had in average accumulated 1.5-fold less than uninfected ones.

In the cystacanth of $P$. minutus, the cadmium accumulation was also described by a dose-response relationship (Fig. 2). Indeed, P. minutus cystacanths from gammarids exposed to $6 \mu \mathrm{g} \mathrm{Cd} \mathrm{L}^{-1}$ tended to accumulate more cadmium than their respective controls. Moreover, P. minutus from individuals exposed to $18 \mu \mathrm{g} \mathrm{Cd} \mathrm{L}^{-1}$ showed significantly higher cadmium concentrations than their respective control. No difference was observed in the cystacanth accumulation according to the host gender.

Results revealed that $P$. minutus cystacanth accumulated less cadmium concentration than $G$. roeseli host. In fact, according to the cadmium concentration in the exposure medium, gammarids had on average from 3 to 15 times more cadmium than their respective cystacanths. A linear relationship between both cadmium concentrations in $G$. roeseli and P. minutus was observed (Fig. 3). Slopes of relationships between the cadmium concentrations in 


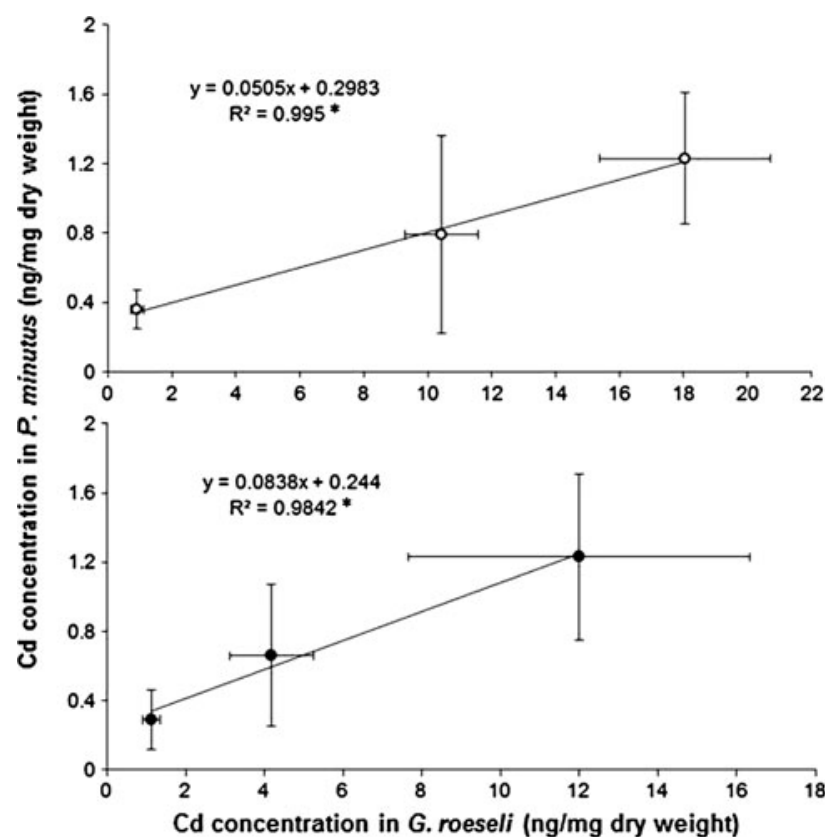

Fig. 3 Relationship between cadmium concentrations in $P$. minutus body tissues and $G$. roeseli females (open circle) and males (filled circle) body tissues after $96 \mathrm{~h}$ of exposure. Asterisks indicate $p$ value $<0.015$

P. minutus and its host were approximately the same for both genders (ANCOVA test, $p=0.21$ ).

\section{Bioconcentration factors}

BCFs were evaluated in $G$. roeseli males and females, uninfected or infected and exposed to 6 and $18 \mu \mathrm{g} \mathrm{Cd} \mathrm{L}^{-1}$. Results confirmed that uninfected gammarids accumulated more cadmium than infected ones (Fig. 4). Whatever the individual gender and the cadmium concentration, uninfected $G$. roeseli had a BCF value higher than infected ones. When infected, BCFs were not different according to the cadmium concentration; while BCFs were higher for uninfected gammarid exposed at $6 \mu \mathrm{g} \mathrm{Cd} \mathrm{L}^{-1}$ (130 on average) than for uninfected ones exposed to $18 \mu \mathrm{g} \mathrm{Cd} \mathrm{L}^{-1}$ (85 on average).

\section{Discussion}

This study was carried out to investigate the effect of the acanthocephalan parasite $P$. minutus on the mortality of its intermediate host $G$. roeseli, exposed to cadmium, especially on its $\mathrm{LC}_{50-96 \mathrm{~h}}$ value and cadmium bioaccumulation.

The $\mathrm{LC}_{50-96 \mathrm{~h}}$ values showed that gammarids have different mortality depending on gender, and infection status. Indeed, in the absence of $P$. minutus, females were two times less sensitive than males. This could be due to higher

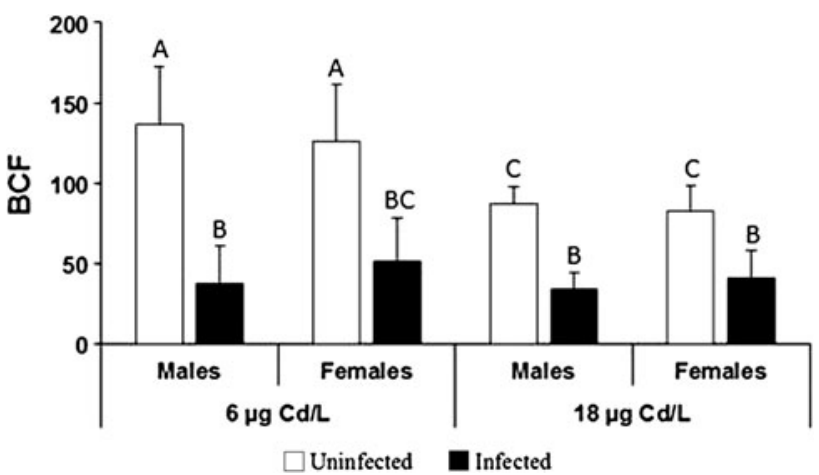

Fig. 4 Bioconcentration factors (BCFs) of G. roeseli according to the gender, the infection status and the cadmium exposure. Five individuals were analyzed for each condition. Different letters above the bars indicate significantly different values $(p$ values $<0.05)$

antitoxic defences reflecting by higher antioxidant enzyme activities (Sroda and Cossu-Leguille 2011a) or higher reduced glutathione concentration (Gismondi et al. unpublished data), but also due to higher energy reserves in females, for reproductive demand, and mobilized if necessary for antitoxic defence syntheses. However, previous studies reported different mortality between genders in a pollutant context. Sroda and Cossu-Leguille (2011b) demonstrated that females of $G$. roeseli and Dikerogammarus villosus were more sensitive to copper than respective males, the converse of our results with cadmium. G. roeseli submitted to a salinity stress revealed a significant higher sensitivity of females in survival, ventilation and ionoregulation (Sornom et al. 2010). When authors have reported a lower mortality of females in comparison to males (Emery 1970; Benoit et al. 1976; Heit and Fingerman 1977, our study), the tested substances were always a non-essential molecule (e.g. cadmium, mercury, cresol).

In our study, cadmium $\mathrm{LC}_{50-96 \mathrm{~h}}$ of uninfected G. roeseli was in the same range that those obtained by Felten et al. (2008), $82 \mu \mathrm{g} \mathrm{Cd} \mathrm{L}^{-1}$ for G. pulex. This highlighted that male gammarids infected by $P$. minutus were more resistant to cadmium exposure than uninfected ones, while infected females were more sensitive than uninfected ones. Female results were in agreement with McCahon et al. (1988) who had determined cadmium LC $_{50}$ value higher for uninfected G. pulex than P. laevis-infected ones. Similarly, Brown and Pascoe (1989) showed that P. laevisinfected G. pulex exposed to $2.1 \mu \mathrm{g} \mathrm{Cd} \mathrm{L}{ }^{-1}$ died faster than uninfected ones. In the present study, the difference observed between cadmium $\mathrm{LC}_{50-96 \mathrm{~h}}$ of uninfected and infected males illustrates a help from the parasite to its host to face with cadmium stress, what contributes to keep it alive. The parasite help could be due to its antitoxic defences such as heat shock protein 70 increased in 
$P$. minutus exposed to palladium (Sures and Radszuweit 2007), or catalase activity present in secretion products and total extracts as observed in nematode or helminth parasites (Dzik 2006; Morassutti et al. 2011). By this action, $P$. minutus could increase its own survival and favour its transmission to its final vertebrate host, a water bird.

The gammarid death could be closely related to a modification of cadmium accumulation. Cadmium accumulation in gammarids has been described in the literature for G. pulex (Stuhlbacher and Maltby 1992; Felten et al. 2008; Vellinger et al. 2012), G. locustra (Clason and Zauke 2000), or G. oceanicus (Zauke et al. 2003), but no study has been devoted to $G$. roeseli and only a few ones have investigated the influence of parasite on the metal bioaccumulation in the host. The present work highlighted that infected $G$. roeseli accumulated less cadmium in their body-whole than uninfected ones, conducting to the weakest BCF in P. minutus-infected gammarids. This result was in agreement with Heinonen (2000) in Pisidium amnicum clams who observed lower BCF in trematodeinfected individuals than in uninfected ones. Our results have shown that $P$. minutus had absorbed cadmium. The cystacanth lives in the haemocoel of $G$. roeseli, surrounded by the haemolymph which contain toxic metals when individuals are exposed to pollutants (Xu and Pascoe (1993): G. pulex exposed to zinc). The cadmium accumulation by an acanthocephalan parasite has already been determined in $P$. laevis infecting $G$. pulex (Brown and Pascoe 1989). Moreover, other metal pollutants can be accumulated by acanthocephalan cystacanth, as palladium in P. minutus cystacanth (Sures and Radszuweit 2007).

Regarding results of this work, $P$. minutus could influence the mortality of $G$. roeseli males by influencing the cadmium bioaccumulation. Indeed, a weak uptake of cadmium by the host could lead to a weak formation of reactive oxygen species, responsible of cellular damage in organisms (Sies 1986).

In contrast of $G$. roeseli male results, $G$. roeseli females were more sensitive to cadmium when $P$. minutus was present, although their BCF and the cadmium concentration in the body-whole were weaker compared to uninfected ones. This higher mortality could be explained by the presence of other parasites as vertically-transmitted microsporidia parasites which are found in many arthropod species (Terry et al. 1999; Ironside et al. 2003; Weedall et al. 2006; Haine et al. 2007), especially in females (Haine et al. 2004). In a previous study, we demonstrated that these microsporidia parasites accentuated oxidative stress in $G$. roeseli females exposed to cadmium (Gismondi et al. 2012). Results obtained in the present study suggested that the potential presence of two parasites (i.e. P. minutus and vertically-transmitted microsporidia) could weaken the host survival and accentuate the cadmium stress.
Acknowledgments This study was supported by the French Ministry of Education and Research (Ministère de l'Enseignement Supérieur et de la Recherche) we sincerely thanks here. The present work takes part of the research program EC2CO (Ecosphère Continentale et Côtière). We thank Philippe Rousselle for cadmium concentration analysis. We wish to thank the anonymous reviewers for their helpful comments on a previous draft of this paper.

\section{References}

Baudrimont M, de Montaudouin X, Palvadeau A (2006) Impact of digenean parasite infection on metallothionein synthesis by the cockle (Cerastoderma edule): a multivariate field monitoring. Mar Pollut Bull 52:494-502

Bauer A, Haine ER, Perrot-Minnot MJ, Rigaud T (2005) The acanthocephalan parasite Polymorphus minutus alters the geotactic and clinging behaviours of two sympatric amphipod hosts: the native Gammarus pulex and the invasive Gammarus roeseli. J Zool 267:39-43

Benoit DA, Leonard EN, Christensen GM, Fiandt JT (1976) Toxic effects of cadmium on three generations of brook trout (Salvelinus fontinalis). Trans Am Fish Soc 105:550-560

Brown AF, Pascoe D (1989) Parasitism and host sensitivity to cadmium: an acanthocephalan infection of the freshwater amphipod Gammarus pulex. J Appl Ecol 26:473-487

Cézilly F, Gregoire A, Bertin A (2000) Conflict between co-occurring manipulative parasites? An experimental study of the joint influence of two acanthocephalan parasites on the behaviour of Gammarus pulex. Parasitology 120:625-630

Clason B, Zauke GP (2000) Bioaccumulation of trace metals in marine and estuarine amphipods: evaluation and verification of toxicokinetic models. Can J Fish Aquat Sci 57:1410-1422

Cornet S, Franceschi N, Bauer A, Rigaud T, Moret Y (2009) Immune depression induced by acanthocephalan parasites in their intermediate crustacean host: consequences for the risk of superinfection and links with host behavioural manipulation. Int $\mathbf{J}$ Parasitol 39:221-229

Duquesne S, Riddle M, Schulz R, Liess M (2000) Effects of contaminants in the Antarctic environment-potential of the gammarid amphipod crustacean Paramorea walkeri as a biological indicator for Antarctic ecosystems based on toxicity and bioaccumulation of copper and cadmium. Aquat Toxicol 49:131-143

Dzik JM (2006) Molecules released by helminth parasites involved in host colonization. Acta Biochim Pol 53:33-64

Emery RM (1970) The comparative acute toxicity of cresol to two benthic crustaceans. Water Res 4:485-491

Felten V, Charmantier G, Mons R, Geffard A, Rousselle P, Coquery M, Garric J, Geffard O (2008) Physiological and behavioural responses of Gammarus pulex (Crustacea: Amphipoda) exposed to cadmium. Aquat Toxicol 86:413-425

Gismondi E, Rigaud T, Beisel JN, Cossu-Leguille C (2012) Microsporidia parasites disrupt the responses to cadmium exposure in a gammarid. Environ Pollut 160:17-23

Haine ER, Brondani E, Hume KD, Perrot-Minnot MJ, Gaillard M (2004) Coexistence of three microsporidia parasites in populations of the freshwater amphipod Gammarus roeseli: evidence for vertical transmission and positive effect on reproduction. Int J Parasitol 34:1137-1146

Haine ER, Motreuil S, Rigaud T (2007) Infection by a verticallytransmitted microsporidian parasite is associated with a femalebiased sex ratio and survival advantage in the amphipod Gammarus roeseli. Parasitology 134:1363-1367 
Heinonen JVKK (2000) Toxicokinetics of 2,4,5-trichlorophenol and benzo(a)pyrene in the clam Pisidium amnicum: effects of seasonal temperatures and trematode parasites. Arch Environ Contam Toxicol 39:352-359

Heit M, Fingerman M (1977) The influences of size, sex and temperature on the toxicity of mercury to two species of crayfishes. Bull Environ Contam Toxicol 18:572-580

Ironside JE, Dunn AM, Rollinson D, Smith JE (2003) Two species of feminizing microsporidian parasite coexist in populations of Gammarus duebeni. J Evol Biol 1:467-473

Kennedy CR (2006) Ecology of the Acanthocephala. Cambridge University Press, Cambridge

Lagrue C, Kaldonski N, Perrot-Minnot MJ, Motreuil S, Bollache L (2007) Modification of hosts' behavior by a parasite: field evidence for adaptive manipulation. Ecology 88:2839-2847

Marcogliese DJ, Pietrock M (2011) Combined effects of parasites and contaminants on animal health: parasites do matter. Trends Parasitol 27:123-130

Marcogliese DJ, Brambilla L, Gagné F, Gendron AD (2005) Joint effects of parasitism and pollution on oxidative stress biomarkers in yellow perch Perca flavescens. Dis Aquat Organ 63:77-84

McCahon CP, Brown AF, Pascoe D (1988) The effect of the acanthocephalan Pomphorhynchus laevis (Müller 1776) on the acute toxicity of cadmium to its intermediate host, the amphipod Gammarus pulex (L.). Arch Environ Contam Toxicol 17:239243

Médoc V, Beisel JN (2009) Field evidence for non-host predator avoidance in a manipulated amphipod. Naturwissenschaften 96:513-523

Médoc V, Bollache L, Beisel JN (2006) Host manipulation of a freshwater crustacean (Gammarus roeseli) by an acanthocephalan parasite (Polymorphus minutus) in a biological invasion context. Int J Parasitol 36:1351-1358

Minguez L, Meyer A, Molloy D, Giambérini L (2009) Interactions between parasitism and biological responses in zebra mussels (Dreissena polymorpha): Importance in ecotoxicological studies. Environ Res 109:843-850

Morassutti AL, Pinto PM, Dutra BK, Oliveira GT, Ferreira HB, Graeff-Teixeira C (2011) Detection of anti-oxidant enzymatic activities and purification of glutathione transferases from Angiostrongylus cantonensis. Exp Parasitol 127:365-369

Plaistow SJ, Troussard JP, Cézilly F (2001) The effect of the acanthocephalan parasite Pomphorhynchus laevis on the lipid and glycogen content of its intermediate host Gammarus pulex. Int J Parasitol 31:346-351
Sies H (1986) Biochemistry of oxidative stress. Angew Chem Int Ed 25:1058-1071

Sornom P, Felten V, Médoc V, Sroda S, Rousselle P, Beisel JN (2010) Effect of gender on physiological and behavioural responses of Gammarus roeseli (Crustacea Amphipoda) to salinity and temperature. Environ Pollut 158:1288-1295

Sroda S, Cossu-Leguille C (2011a) Seasonal variability of antioxidant biomarkers and energy reserves in the freshwater gammarid Gammarus roeseli. Chemosphere 83:538-544

Sroda S, Cossu-Leguille C (2011b) Effects of sublethal copper exposure on two gammarid species: which is the best competitor? Ecotoxicology 20:264-273

Stuhlbacher A, Maltby L (1992) Cadmium resistance in Gammarus pulex (L.). Arch Environ Contam Toxicol 22:319-324

Sures B (2004) Environmental parasitology: relevancy of parasites in monitoring environmental pollution. Trends Parasitol 20:170-177

Sures B, Radszuweit H (2007) Pollution-induced heat shock protein expression in the amphipod Gammarus roeseli is affected by larvae of Polymorphus minutus (Acanthocephala). J Helminthol 81:191-197

Taylor D (1983) The significance of the accumulation of cadmium by aquatic organisms. Ecotoxicol Environ Safe 7:33-42

Terry RS, Smith J, Bouchon D, Rigaud T, Duncan P, Sharpe R, Dunn AM (1999) Ultrastructural characterisation and molecular taxonomic identification of Nosema granulosis n. sp., a transovarially transmitted feminising (TTF) microsporidium. J Eukaryot Microbiol 46:492-499

Vellinger C, Parant M, Rousselle P, Immel F, Wagner P, UsseglioPolatera P (2012) Comparison of arsenate and cadmium toxicity in a freshwater amphipod (Gammarus pulex). Environ Pollut 160:66-73

Vindimian É, Garric J, Flammarion P, Thybaud É (1999) An index of effluent aquatic toxicity designed by partial least squares regression, using acute and chronic tests and expert judgements. Environ Toxicol Chem 18:2386-2391

Weedall RT, Robinson M, Smith J, Dunn AM (2006) Targeting of host cell lineages by vertically transmitted, feminising microsporidia. Int J Parasitol 36:749-756

Xu Q, Pascoe D (1993) The bioconcentration of zinc by Gammarus pulex (L.) and the application of a kinetic model to determine bioconcentration factors. Water Res 27:1683-1688

Zauke GP, Clason B, Savinov VM, Savinova T (2003) Heavy metals of inshore benthic invertebrates from the Barents Sea. Sci Total Environ 306:99-110 